INTERDISCIPLINARIA ARCHAEOLOGICA NATURAL SCIENCES IN ARCHAEOLOGY

\title{
Reinventing the Wheel: Perpetual Innovation in Sinhalese Potter Assemblages
}

\author{
Deborah Winslow ${ }^{1 *}$ \\ ${ }^{1}$ School for Advanced Research, 660 Garcia St., Santa Fe, New Mexico 87505, USA
}

\section{ARTICLE INFO}

\section{Article history:}

Received: $3^{\text {rd }}$ February 2021

Accepted: $16^{\text {th }}$ August 2021

DOI: http://dx.doi.org/10.24916/iansa.2021.2.11

Key words:

potter's wheel

technological change

longitudinal ethnography

dynamic systems

spatio-temporal scale

$20^{\text {th }} \& 21^{\text {st }}$ centuries

Sri Lanka

\begin{abstract}
$A B S T R A C T$
This paper describes a linked series of potter's wheel reinventions and abandonments from the mid- $20^{\text {th }}$ century through 2013 . The wheel is analysed as one element in a complex and dynamic assemblage of people, resources, technologies, meanings, places, and time. Primary data come from ethnographic observations and interviews in a Sinhalese Sri Lankan potter community followed since 1974. As they shifted from one potter's wheel to another, these potters have altered social and physical supporting technologies for procuring and preparing clay, acquiring fuel, organising labour, and marketing pottery. Some, having reached the limits of a wheel's capabilities and their own bodies, have abandoned the wheel in favour of moulds and mechanical presses, setting off more cascades of change. Their experiences help to clarify the adaptive capacities and limitations of both potter's wheels and their users. As this story unfolds in often unanticipated ways, it reveals the importance of attending to spatiotemporal scale. Locally, the wheel highlights the relatively fast-changing affordances and constraints with which individual potters, households, and communities engage. But the wheel also brings into focus the slower moving consequences of regional heterogeneities and paths laid down by national colonial and post-colonial policies decades ago.
\end{abstract}

\section{Introduction}

The earliest appearances of potter's wheels in the archaeological record have been documented comprehensively (eg. Berg, 2020; Evely, 1988; Rice, 1987, p.7, pp.128-136). The wheel's advent is associated with early urbanism, artisanal specialisation, and socioeconomic differentiation. Generally, it is seen as a technological step forward, even when employed for pottery shaping rather than throwing, complementing rather than replacing handbuilding methods (Crewe and Knappett, 2012, p.178, p.181; Knappett and van der Leeuw, 2014, pp.76-77). The wheel's rotative kinetic energy allowed potters to produce lighter, more symmetrical, and more standardised wares. Throwing also improved efficiency and facilitated mass production (Roux, 2003, pp.2-3; 2010, pp.221-222). Therefore, when it sometimes has been observed that the wheel's adoption was followed by its decline or even disappearance, this has posed a puzzle for analysts.
Archaeologists have proposed diverse solutions to this puzzle, including: ancient political crises that produced ethnic differentiation with parallel technological heterogeneity (Franken and London, 1995, pp.219-221); depletion of deposits of clay sufficiently plastic and free of intrusions for wheel throwing (Magrill and Middleton, 2001, p.137); or the failure of wheel technology to be adopted by a sufficiently large network of potters to achieve redundancy and ensure cultural transmission (Roux, 2010, p.228; also, Knappett and van der Leeuw, 2014, pp.82-83). Each solution answers to a specific historical context; all accept that wheel-use decline is a setback in need of explanation. Here, in contrast, I present an instance in which wheel abandonment produced economic, social, and technological advancement, increasing incomes, social status, and productivity. My case concerns rural potters in Sri Lanka who gave up the wheel for some types of pottery. Doing so, they set off a cascade of other changes and thus transformed their industry's "dynamic system" (Roux, 2003). 


\section{Methodology and results: longitudinal ethnography}

As a cultural anthropologist, my primary methods are ethnographic: participant observation, semi-structured interviewing, life history interviews, and key informant conversations. I also have consulted the Colonial Record Office Library in London, the National Archives in Colombo, and private archives to cull historical information from Administration Reports and other $19^{\text {th }}$ and $20^{\text {th }}$ century sources. Fieldwork in Sri Lanka has totalled about 55 months: longer stays in 1973-1976 (33 months), 1992 (7 months), 2004 (2 months), and 2013 (9 months), with shorter trips of 1 to 6 weeks between.

Here I focus on a potter village that I call Walangama. Typically, I resided with a Walangama family for months at a time. On each longer trip, I systematically visited almost every Walangama household, usually more than once, for conversations that lasted hours. I updated demographics and kinship information, learned about social and economic developments, watched people work, gossiped, and sometimes collected more specialised information, such as a one-time network survey and a series of life history interviews. I have compiled some of these data into a relational database. Other information, including that gained by participating in Walangama life, informs the qualitative aspects of this account. I also have visited other potter communities, tile factories, and dairies to create a larger picture. My historical information comes from interviews with older Walangama residents and retired officials, archival records, and secondary sources. Together, this information allows me to piece together my understanding of how the Walangama pottery industry has changed in the context of other changes locally, regionally, and nationally: a longitudinal ethnography.

\subsection{The early $20^{\text {th }}$ century: the collapse of a traditional subsistence system}

Like most Sinhalese villages, Walangama was once quite small (Denham, 1912, pp.30-33). Between 1881 and 1921, its population averaged 102 people, all of Potter (Badahäla or Kumbāl) caste. But after the advent of malarial control measures such as DDT, census records and my own counts show that the population rose quickly: 213 people (1952), 359 people (1964), approximately 600 people (1975), and around 1000 people in 2013 (Winslow, 2016, p.226 n.3). That mid-century jump, which doubled the population, was particularly detrimental to Walangama's multi-pronged subsistence strategy.

Walangama people did not always rely primarily on pottery-making; they preferred farming. They grew rice on their own fields and gardened dry grains and vegetables on nearby Crown (government-owned) lands. But pottery was a necessary fallback. The village's land base is small and because it is located in the island's drought-prone intermediate climatic zone, rice farming is unreliable; furthermore, Crown land access was never guaranteed. Pottery-making, too, had constraints: limited technology, inadequate workspace, and insufficient markets. Yet, while singly precarious, together farming, gardening, and potting once formed a resilient subsistence system. Unfortunately, by 1948, as Sri Lanka (then, Ceylon) achieved independence from Great Britain, Walangama was faced with the twin calamities of a rising population and the loss of their garden lands to coconut estate planters. Walangama stories of the 1940s were dismal tales of overcrowded houses, crying children, and chronic food insecurity.

\subsection{Post-independence: improving the potter's wheel}

I first heard those stories in 1974; by then, Walangama's situation had improved. The upturn began in July 1949 when one Albert Perera appeared on his bicycle, sent by the government to start up a "Pottery Demonstration Centre." Walangama residents had petitioned their new, post-Independence Member of Parliament for aid. The MP had responded not by giving them the agricultural land they sought but by convincing the Ministry of Industries' Cottage Industries Division to include Walangama in its program to "assist those engaged in village pottery" (Samarasinghe, 1956, p.J4). This program was one of many through which the new government continued colonial social welfare policies rooted in Fabian socialism (Jayasuriya, 2001; Winslow, 2003, pp.53-54). By the time of Mr. Perera's arrival, approximately 30 such centres had been established around the island (van Langenberg, 1951, p.GG19). As the Acting Director of Industries during the war years later wrote, "One of the main objects of government intervention was to popularise the use of modern wheels to throw and turn the clay body" (van Langenberg, 1951, p.GG21, emphasis added). Local "officers-in-charge," such as Mr. Perera, as well as visiting inspectors, maintained a log of their activities. This log reveals that two months after Mr. Perera arrived in Walangama, he visited the Kurunegala railway station to "remove pottery wheels" - that is, to collect them to take to Walangama (Logbook: 8 September 1949).

Walangama's traditional wheels were "floor wheels" (bima poruva), similar to southern India's pivoted block wheels (Saraswati and Behura, 1966, pp.10-11). The 1948 floor wheels seem to have been unchanged from those described for Sinhalese potters decades earlier: "...a circular board about $2 \frac{1}{2}$ feet $[76.2 \mathrm{~cm}]$ in diameter mounted on a stone pivot which fits into a larger stone socket embedded in the ground, the horizontal surface of the wheel itself standing not more than six inches above the ground" (Coomaraswamy, 1956 [1908], p.219). By 1974, when I first went to Walangama, floor wheels were no longer used; but in 2008, I observed one in another village. I was impressed by its instability. The potter was able to throw small pots, but the wheel wobbled on its pivot and to exert sufficient pressure against enough clay to make larger vessels, she would have needed an assistant.

The floor wheels were homemade, carved from circular sections excised from the buttress roots of trees (eg. Ficus retusa) found locally along streams. The round was roughly shaped with an axe, finished with finer tools, and surfaced 


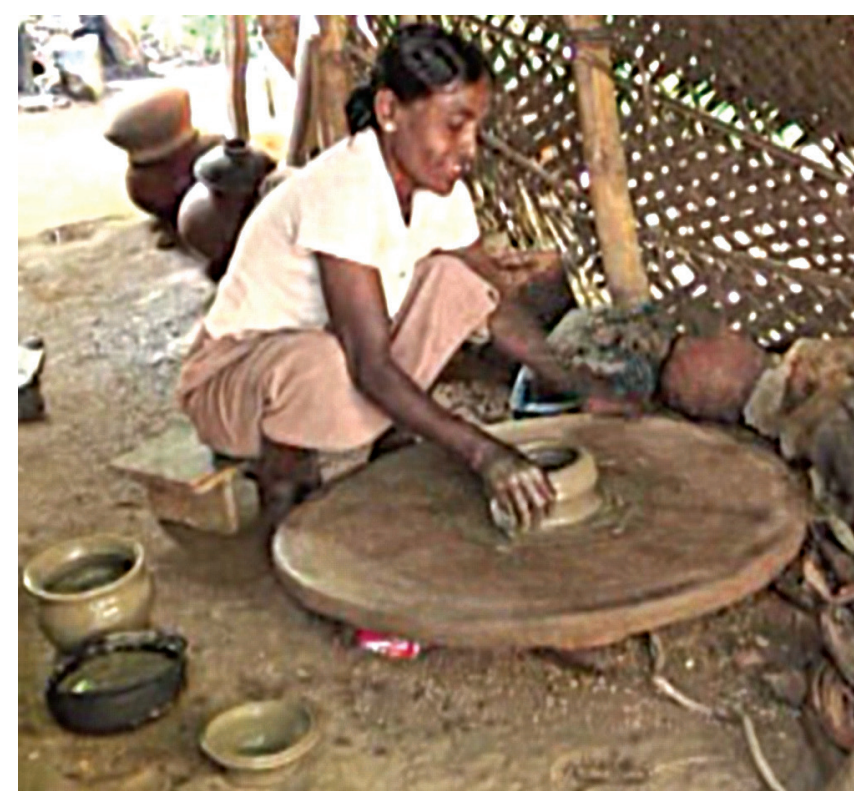

Figure 1. A Sinhalese potter using a floor wheel. Photo: D. Winslow, 2008.

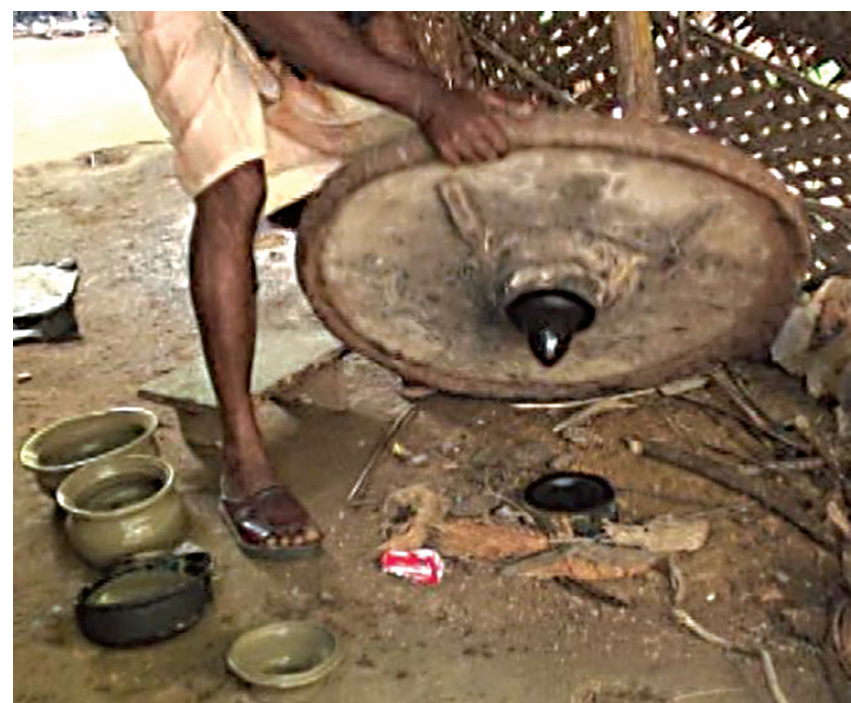

Figure 2. A view of the underside of the floor wheel (Figure 1) showing the pivot and socket. Photo: D. Winslow, 2008.

with clay. The socket-and-pivot set was typically of granite, purchased from itinerant stoneworkers or recycled from older wheels. I also have seen sets made of iron (such as in Figure 2). The pivot was attached to the wheel's underside with a mixture of an adhesive substance like jack tree gum, and fibrous filler such as human hair or coconut husk fibre.

Potters used the floor wheels to throw off a hump. After forming the mouth, thick walls, and overall shape, they detached each pot from the hump, drawing a wire or thin strip of bamboo through the base high enough to leave the bottom open. After drying to leather stage, the pot was paddled (on the outside) against an anvil (on the inside) to thin the walls and extend them into a rounded bottom. If a foot was desired, the pot was set upside-down on the wheel, which was rotated while a snake of clay was attached

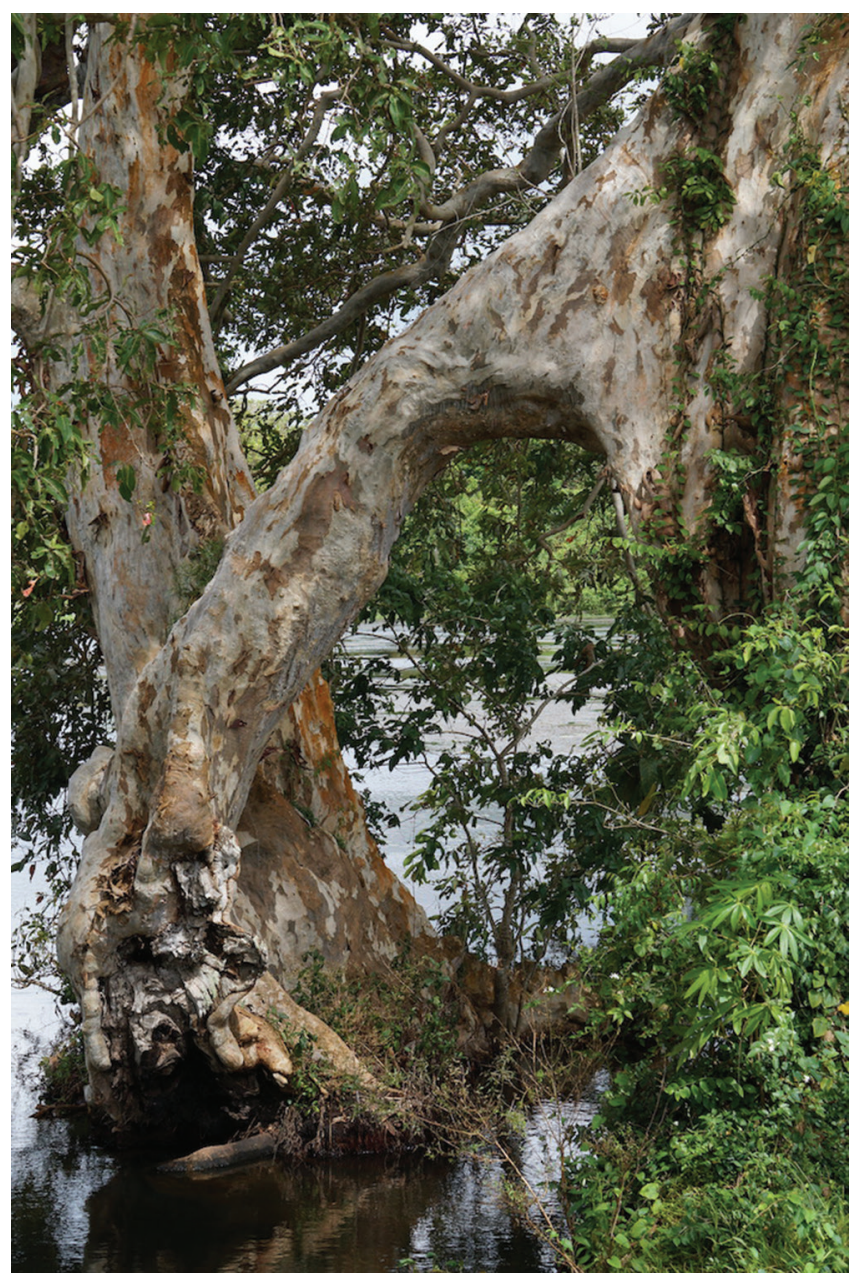

Figure 3. Buttress root of tree (Ficus retusa), showing scar left by removing wood for potter's wheel. Photo: D. Winslow, 2013.

and shaped. This technology is found throughout South Asia (Saraswati and Behura, 1966). In Sri Lanka, it dates back to at least the middle of the first millennium BC (Schenk, 2001, p.60; Somadeva, 2006, p.295).

Mr. Perera's "modern" wheels, still used in Walangama, are hand-turned, single wheels, $65-70 \mathrm{~cm}$ in diameter. They may be hand-carved, but most are made of milled boards joined underneath with wood or metal straps and shaped by a carpenter. Because they are mounted at chair height on a metal pipe set in a ball-bearing race, they are more comfortable for the potter and sustain faster, longer spins. They, too, are combined with paddle-and-anvil finishing. A potter can work productively solo for all but the largest pots. A married couple might work alongside each other, sharing all aspects of potting; they might divide the work, with the more expert one throwing while the spouse does the final beating; or one might both throw and beat while his or her spouse is engaged in child care, farming, estate labour, or other employment. There is no proscription on women using the wheel and women are among the most skilled potters, but mothers of infants do more childcare and men do more farming (Winslow, 1994). 


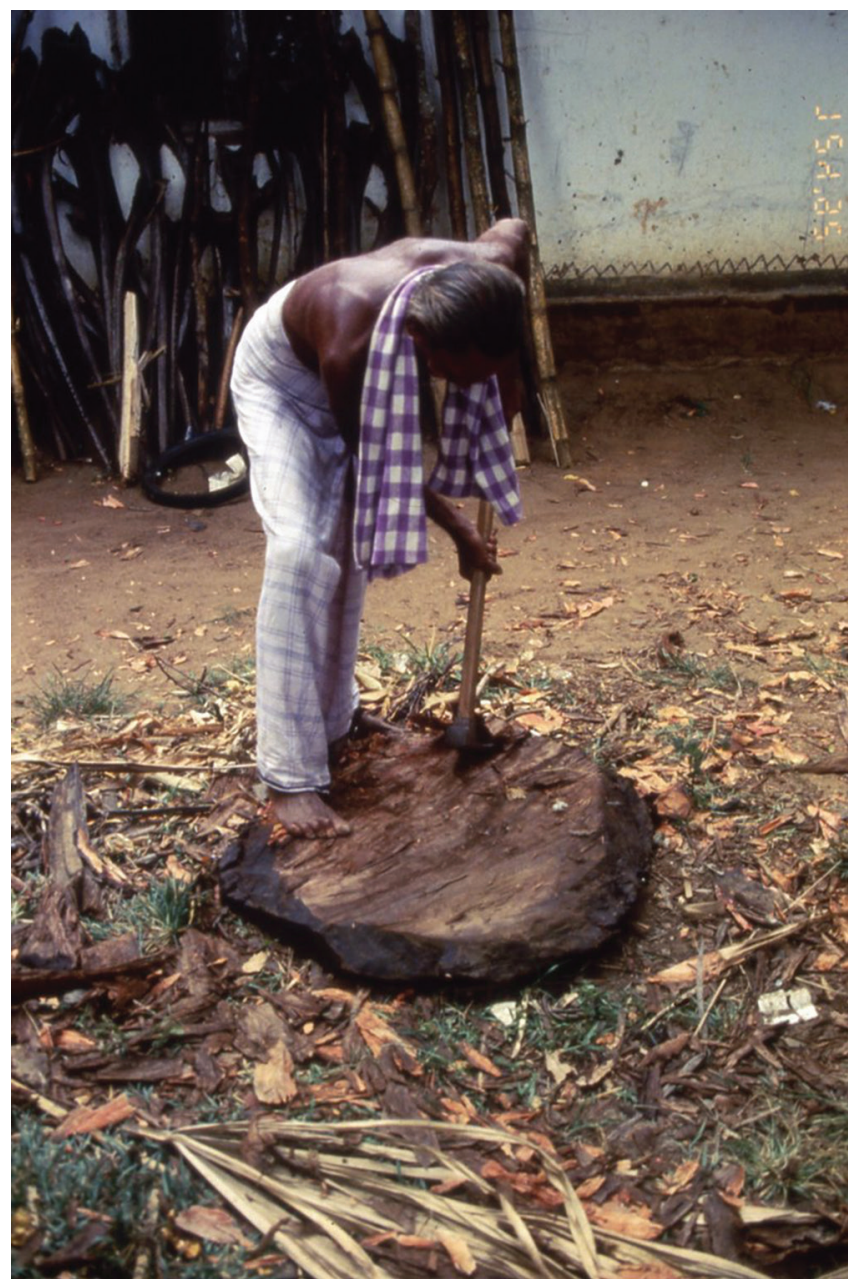

Figure 4. Walangama potter roughing out a potter's wheel from wood cut from tree root. Photo: D. Winslow, 1992.

After their late-1949 introduction, the new wheels were adopted quickly. The government intended that they be used in the pottery centre or purchased for home use. But the potters preferred home workshops and found the price unaffordable, so they soon figured out how to make them (Logbook, 11 March 1952). Within four years, the regional ceramics inspector reported that pottery production had "increased to 25 percent more than the previous year and there is every possibility for further increase in production" (Logbook, 26 February 1953). Indeed, as logbook entries show, Mr. Perera's biggest problem soon became marketing, not production.

Selling pottery became easier after 1950 when the pottery centre became a "pottery society," one of many production and marketing coöperatives established by Sri Lanka's socialist government in the early decades after Independence (Fernando, 1951, p.E35). As coöp members, the potters could sell directly to the coöp and avoid their previous practices of selling in weekly markets, by house-to-house hawking in neighbouring communities, and bartering pots for rice on bullock cart journeys during harvest season. At first, the coöp hoped to purchase a lorry and market pottery collectively. But despite repeated loan applications, the

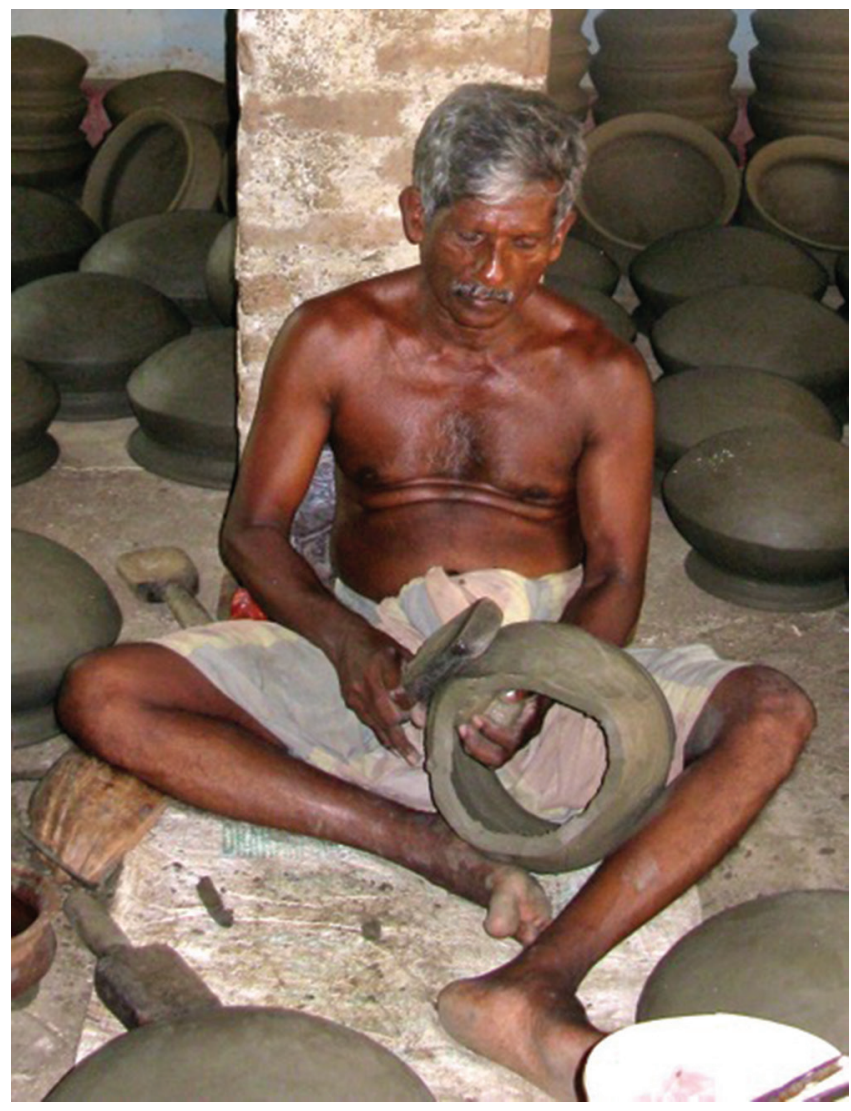

Figure 5. Walangama potter using paddle-and-anvil technique on halfdried pot to thin walls and form rounded bottom. Note the finished pots behind him. Photo: D. Winslow, 2013.

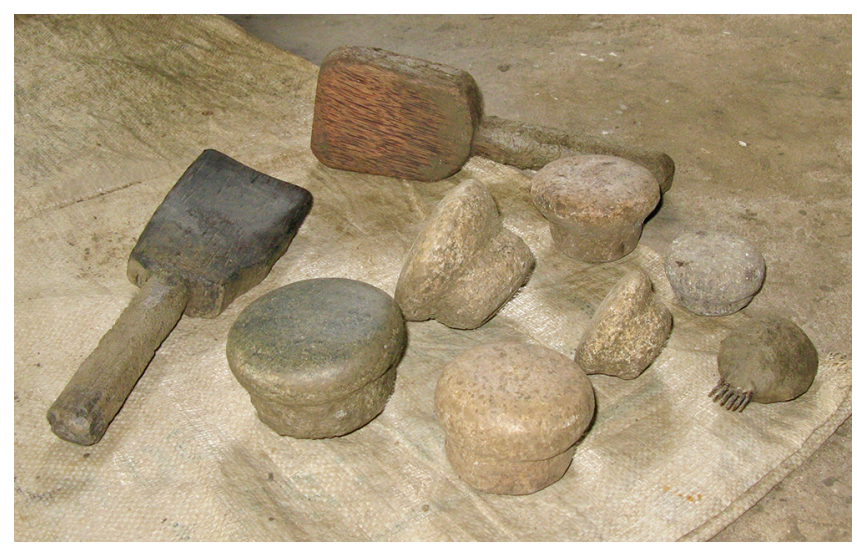

Figure 6. Wooden paddles and granite anvils. Photo: D. Winslow, 2013.

regional inspectors of ceramic coöperatives seem not to have approved this proposal. So, Mr. Perera worked with the coöp leaders to wholesale the pottery to traders, some from the village and some from outside, who transported it in rented lorries throughout the district and beyond. This improved sales and gave village men (and at least one woman) expertise in lorry rentals, contracts, and marketing - skills that served the village well later.

The coöperative faced more challenges: clay and crowding. Clay is locally abundant along water bodies and in fields. Traditionally, it was free for the taking because its 


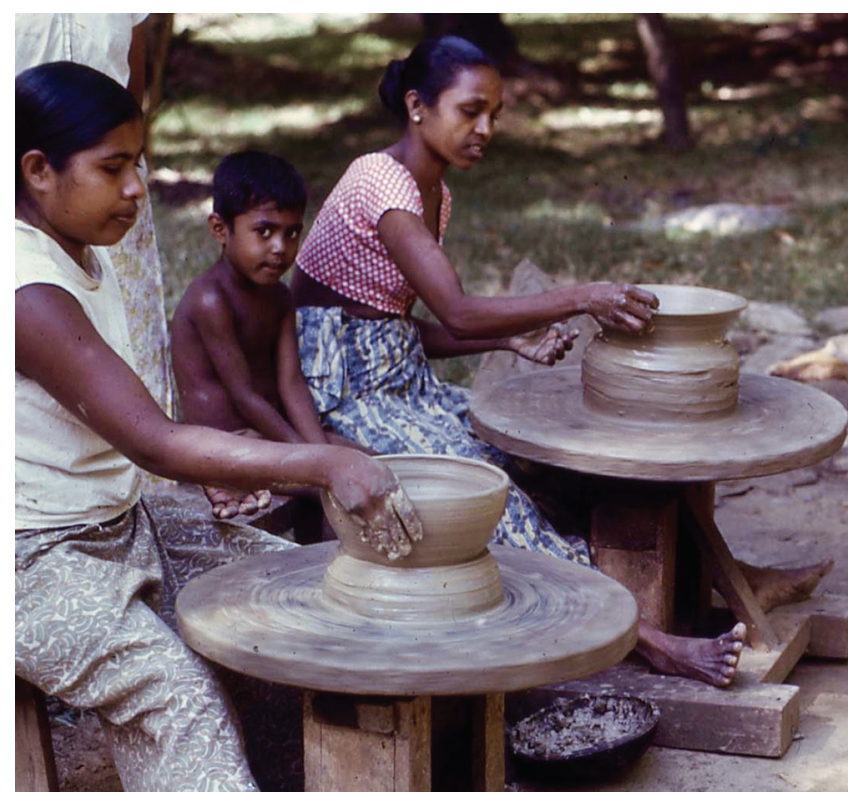

Figure 7. Women using ball-bearing wheels. Photo: D. Winslow, 1975.

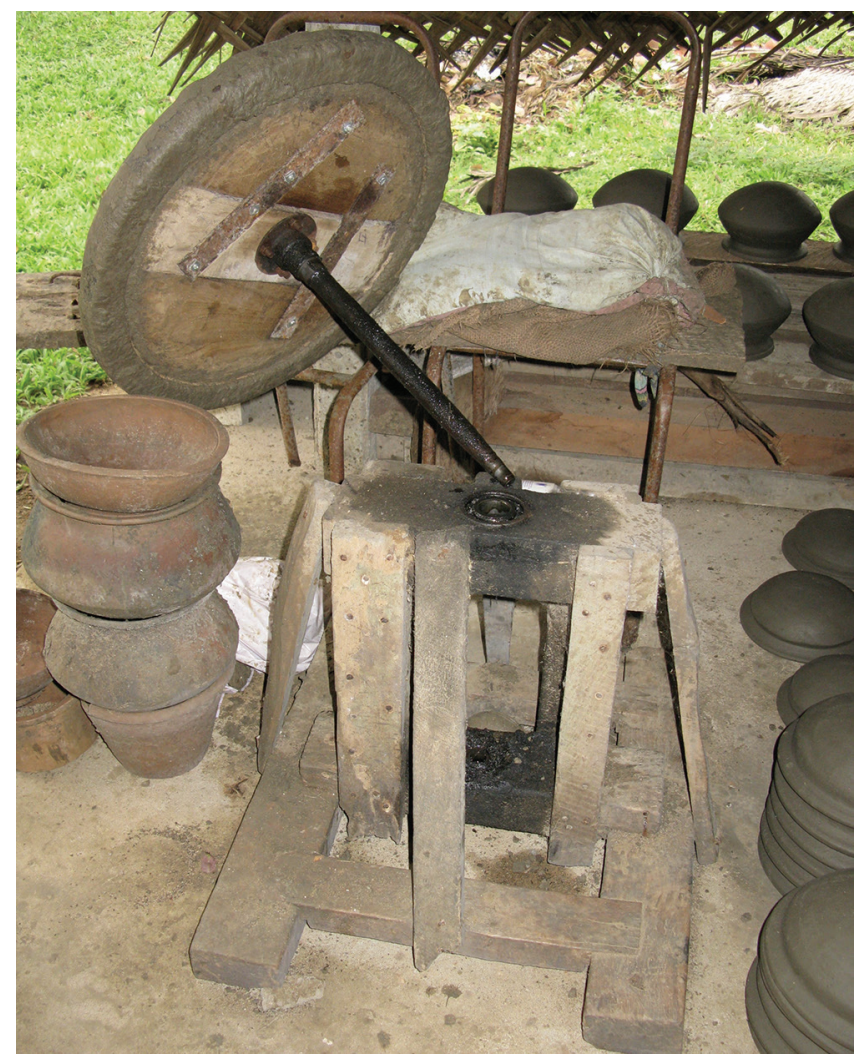

Figure 8. Underside of ball-bearing wheel, showing bearing race. Photo: D. Winslow, 2013.

removal lowered fields and improved irrigation water flow. But after national price supports increased the profitability of rice farming beginning in 1948 (Weerahewa, 2004, p.8), farmers became reluctant to grant access. The government then helped pottery coöperatives purchase clay fields, which the Walangama coöp did in 1954 (Logbook, November 1954; Perera, 1960, J56; Samarasinghe, 1956, J84). Potters also need space enough for workshops, kilns, and areas to shelter drying pots and store clay, kiln fuel, and finished wares. Walangama, hemmed in by coconut estates and with a rising population, lacked room to expand. Village representatives again approached their MP and in keeping with the socialist ethic of the time, he again proved helpful by facilitating Walangama's inclusion in a new national Village Expansion Scheme. In 1955, sixty acres of coconut estate land adjoining Walangama were commandeered by the government. Fifty families received one-acre plots and the balance was reserved for later common uses (Arulpiragasam, 1955, p.A182).

Thus, the robust pottery industry I encountered in 1974 was not a timeless artisanal tradition but the outcome of over two decades of innovations and problem solving. The 1970s were difficult in Sri Lanka; price controls and import substitution policies produced scarcities, unemployment, and social unrest (Athukorala and Jayasuriya, 1994, p.33). But because cooking on three-stone hearths and hauling water in clay pots remained the rural norm, pottery prices tracked inflation (Winslow, 1996, p.711, Figure 2). Walangama household incomes, Rs. 400 to 500 a month, were above average (Gavan and Chandrasekera, 1979, p.19, Table 5). Equally important, when the national economic environment suddenly shifted, Walangama's new pottery-based subsistence system proved sufficiently flexible to adapt, although their wheel did not.

\subsection{The open economy and the potter's wheel's limits} In 1977, the Sri Lankan electorate voted in a government that ran on a neoliberal platform of opening the economy and encouraging foreign investment. Its first major undertaking was the Accelerated Mahaweli Development Project, $150 \mathrm{~km}$ to Walangama's north. It was a massive multi-dam scheme to harness the Mahaweli River for hydroelectric power, provide irrigation for agriculture, resettle landless farmers, and expand rice and dairy farming (Athukorala and Jayasuriya 1994, p.10, n.44). By the early 1990s, the dairy farming component of this scheme had dramatically increased production of buffalo milk yogurt or curd (Winslow, 1996, pp.713-715).

Curd is made and sold in single-use clay pots. Because they are thrown out after a single use, curd pots (kiri haTi, milk pots) are made more quickly, crudely, and from poorer quality clay than ordinary pottery (walan). Many curd producers in the Mahaweli area originally came from the traditional curd producing areas of southern Sri Lanka. Those producers continued to import the needed pots from their home suppliers, $300 \mathrm{~km}$ away. Traditionally, Walangama potters did not make curd pots.

But in 1981, a Walangama man wholesaling coöp pottery in the Mahaweli region noticed the lorry loads of curd pots arriving from the south coast. He realised that because Walangama was much closer, he could profitably underbid the southern suppliers. Leveraging his experience selling coöp pottery, he secured a contract to supply pots to a northern dairy farm. He then returned to Walangama to recruit neighbours and relatives to help him fill the order, paying them a small stipend to learn this new skill. They already made a similar pot, the ätiliya, a shallow pot with 
a rounded bottom used for cooking curries, so they learned quickly.

A decade later, in 1992, I found that Walangama potters were turning out 100,000 curd pots a month while continuing to produce regular pottery. As dairy farms responded to the growing middle class's new taste for curd as a staple food, the demand for curd pots seemed unending. The potters were working overtime to take advantage. I heard the tap-tappity sound of bottoms being beaten into wheel-thrown pots far into the night and first thing every morning.

But much as the advent of modern wheels had spotlighted the floor wheel's limitations, the curd pots revealed stress points in the modern wheel system. I timed a Walangama potter at work. It took her just 10 to 15 seconds to form each curd pot on her wheel and, once leather-dried, 15 seconds or so to beat. She grimaced as she compared her work to making potato chips: identical, relentless, mind-numbing repetition. It was also physically challenging. 1992 was the first time I heard even young potters complain of painful wrists, shoulders, and backs. The increased need for clay exacerbated the difficulties. Clay was dug with short-handled hoes, massed into $20 \mathrm{~kg}$ balls, and hauled to workshops in carts pulled by bullocks or mini-tractors. Water and, sometimes, temper, were then integrated into the clay by trampling, mixing with bare feet. Clay digging was physically hard and time-consuming; non-stop trampling produced swollen and painful knee joints.

The solution to these insupportable stresses turned out to be replacing them with mechanical means: a "mould machine" (achchuwa mäshin) and a "clay mill” (mäti ämbäram). The mould machine is a mechanical press with a long, thick screw that lowers a round metal plate into a hinged metal mould filled with clay. The screw is then reversed, retracting the plate from the mould, which is opened to reveal a completely formed pot. The machines originated in roof tile factories. Once Walangama potters discovered the machines also could form pots (Winslow, 2009, pp.265-266), they had local machine shops adapt them to their needs. The first mould machine appeared in Walangama in the late 1990s. Within a decade, there were over a hundred machines just for curd pots and handmade curd pots had disappeared as completely as had the floor wheels a half-century earlier.

The clay mill crushes intrusions and integrates moisture into clay by drawing it through metal rollers. The first mill appeared in Walangama in 2002, an improvised contraption with a mini-tractor motor, rice mill rollers, and oil drum radiator. After local engineering shops assumed production, the mills were standardised and, eventually, electric. The machines are relatively expensive but some machine owners now process other potters' clay for a small fee, so the technology has spread even to those who continue to make traditional wheel-thrown pottery.

Curd pots have transformed Walangama's pottery industry. In the 1970s, about three-quarters of Walangama households made wheel-thrown pottery. In 2013, I found that almost as many (about two-thirds) continued pottery-making but while some made traditional pottery, others made curd pots, and

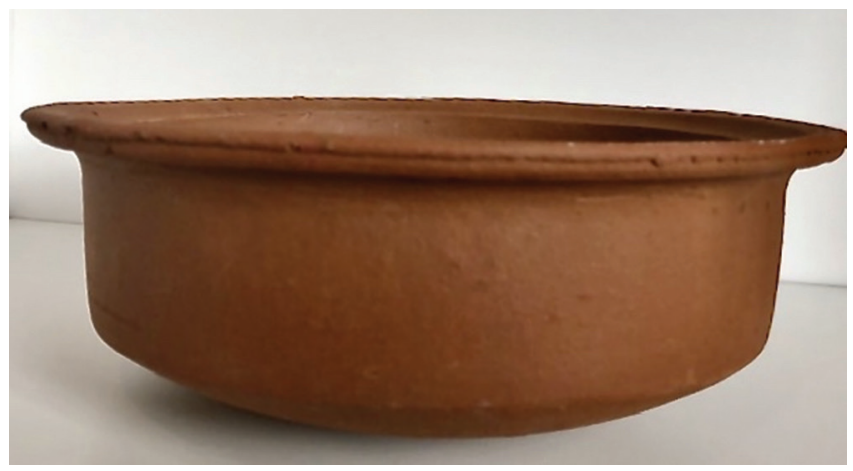

Figure 9. A traditional, wheel-thrown ätiliya vessel. Photo: D. Winslow, 2013.

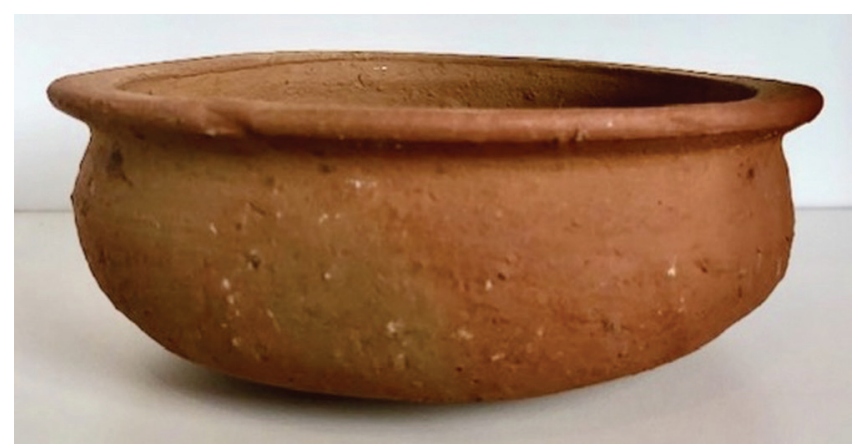

Figure 10. A wheel-thrown curd pot, finished with paddle-and-anvil. Note the intrusions remaining in the poorly cleaned clay. Photo: D. Winslow, 1992.

some households made both. Hardworking traditional potters are as financially successful and respected as anyone, but curd pots are considered more easily profitable because they require less skill and sales are less seasonal. Money is not the only attraction. Young mothers told me that they preferred the mould machines because the mess is less than wheelthrowing. A quick handwash and they are ready to tend to an infant or toddler. The machines also afforded potters new options. Younger potters may borrow mould machines from traders who also supply them clay and kiln fuelwood. In return, the trader buys the pots at a small discount, thus securing a steady supply in what remains a producers' market. As households become more established financially and children reach school age, they can buy their own machines and secure their own supplies. The more entrepreneurial may hire others to help, including non-potters from surrounding villages because operating mould machines is relatively unskilled work. In this way, pottery production increasingly has become more a business and less a stigmatised identity. The coöp once freed their grandparents from the indignities of face-to-face selling; now, the mould machines have freed some from making pottery at all. Whether this will translate into increased internal stratification within Walangama remains to be seen. So far, it has not, perhaps because the community is laced with internal kin ties and has a strong ethic of sharing (Winslow, 2009, pp.260-261).

However, while the machines have solved old problems they also have created new ones. By 2013, curd pot 


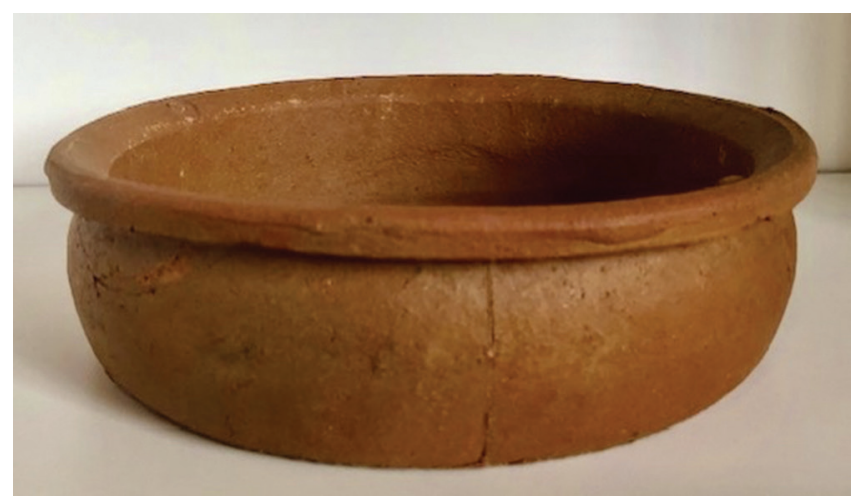

Figure 11. A curd pot made with a mould machine, using clay that has been processed with a clay mill. Note the ridge left by the mould, the flat bottom, and the lack of intrusions. Photo: D. Winslow, 2013.

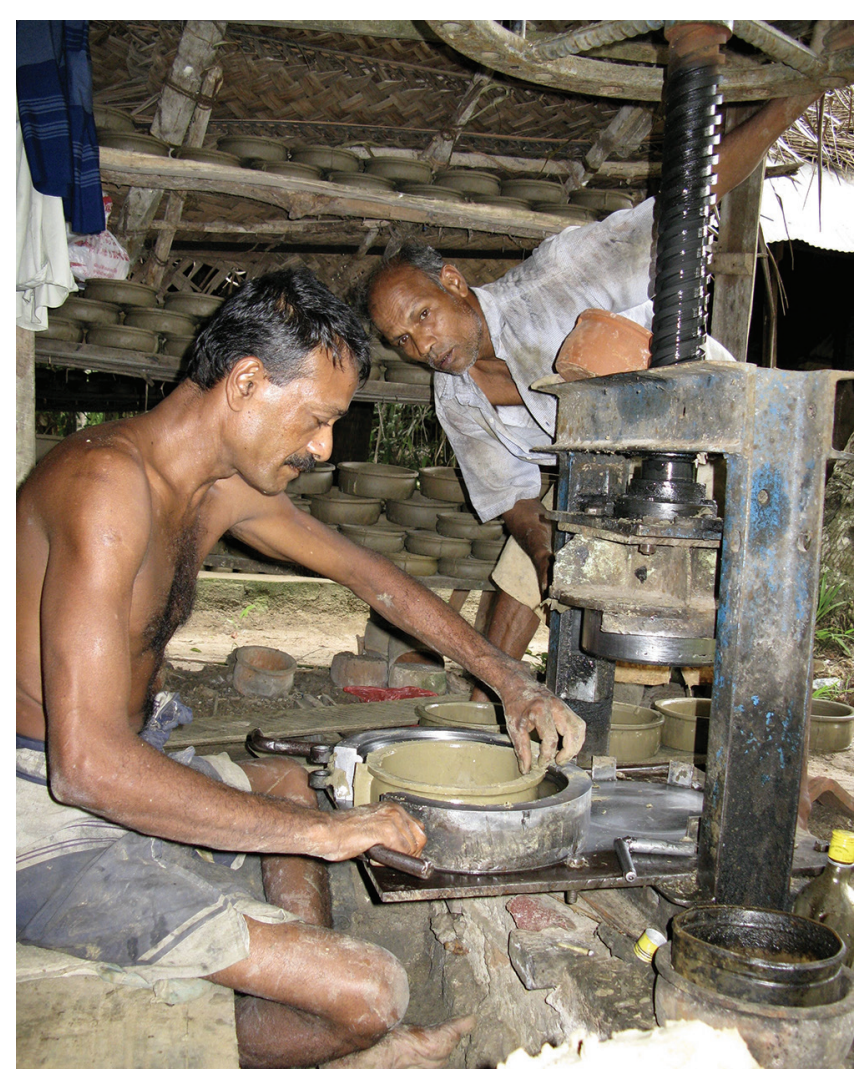

Figure 12. A mould machine in use. The sitting potter is opening the mould to remove the pot. The man standing is operating the screw to lower a plate into the mould and then retract it.

production had expanded to around a million pots a month, making it increasingly time-consuming to secure supplies. The bottoms and walls of moulded pots are thicker, an artefact of the technology, although traders also claim that dairy farms like the heavier pots because they give the impression of more product. Table 1 compares the "one litre" hand-thrown pot (Figure 10) with the "one litre" moulded pot (Figure 11). The moulded pot required about 40 percent more clay for a similar volume.

The coöp's clay field has not been exhausted but because the field's perimeter was excavated first, deep gullies now make accessing the interior difficult. Those who produce a lot of curd pots find it easier to buy clay from farmers. Heavier pots also require more fuelwood to fire. Walangama potters fire their pots in shallow pit kilns built around the pots themselves. There have been some minor modifications, such as constructing a permanent brick wall at one kiln end, but overall the system has changed little despite the changes in the industry. In the 1970s, they used bio-waste husks and branches from nearby coconut estates, but as the world market for coconut oil has declined, estates are being sold for housing development. The increased competition for the waste from the few remaining estates allows estate owners to charge for materials they were once happy to see hauled away for free. In the early 2000 s, the potters supplemented estate wastes with lumber mill scraps, but then a particle board factory was built in their region. The mill buys wood scraps in bulk, undercutting potter access. In 2015, I saw Walangama producers of both traditional pottery and curd pots travelling widely in search of kiln fuel.

\section{Theories, reasoning, and discussion}

In part, Walangama's potter's wheel story illustrates the importance of a dynamic systems approach to understanding technological change. As Roux explained, “...change is not seen as process of adaptation and equilibrium inherent in homeostatic system, but as an emergent property of complex patterns of interaction in real time" (2003, p.6). Thus, in Walangama, change emerged and continues to emerge from perpetual efforts to adapt to changing opportunities and challenges.

Technologies are rarely seamless, perfected totalities. Weak points are inevitable and multi-faceted. In Walangama, dissatisfaction with being easily identified as low-caste potters and the challenge of combining wheel use with daily demands of family life were as much weak points as were the floor wheel's wobbles and handcraft's physical toil. These stresses conditioned their responses to changing opportunities and encouraged people to accept (in the case of ball-bearing wheels) or seek (in the case of curd-pot machines) alternatives. But those responses introduced or illuminated new weak points, such as the pressures on clay and fuel wood. A dynamic system is unlikely ever to reach a point of fixation or stasis because it always contains within it the seeds of change (Allen et al., 2010).

Table 1. Comparison of weights of thrown and moulded one-litre curd-pots.

\begin{tabular}{ccccc}
\hline Pot type & Wt. (grams) & Vol. $(\mathbf{m l})$ & Base thickness $(\mathbf{m m})$ & Outside height $(\mathbf{m m})$ \\
\hline Hand-thrown & 602 & 900 & 5.8 & 50 \\
Moulded & 849 & 950 & 6.5 & 55 \\
\hline
\end{tabular}


But while Roux's dynamic systems framework usefully highlights bottom-up changes, Walangama's experience over the past century shows the importance of extending analyses beyond the micro-scale. At the meso-scale, we are reminded that no community exists in isolation. Walangama is located in the intermediate zone between Sri Lanka's wet and dry zones where, because rainfall fluctuates from year to year, they long relied on pottery-making as a back-up to agriculture. But there have also been locational advantages. The region is rich in low-humic gley soils with deep clay deposits (Panabokke, 1996, Map 1). The coconut estates that thrived in this zone once provided bio-wastes to fuel kilns. A lower population density meant that there was eventual room for expansion. The village lies on a well-travelled road that connected it to the expanding Mahaweli region to the north and to the traditional population centres of Kurunegala, Kandy, and Colombo nearer by.

The subtle importance of these mundane specifics becomes clearer when we compare Walangama with two nearby potter communities, also with good access to clay, workspace, and, until recently, fuelwood. Kelinawala lies about seven $\mathrm{km}$ from Walangama, a walkable distance. Kelinawala potters do not make curd pots and their industry is declining as young people seek other kinds of work. People there told me that their poor road lacks a bus service, and outside traders never came their way. When the Kelinawala pottery society amassed a lorry load, they would ask kinsmen in the Walangama pottery society to pass on the message to traders who only then came to buy, assured that a difficult trip would be worthwhile. Consequently, Kelinawala never developed its own traders, as Walangama did. The second example is Ambagahawewa, also about seven $\mathrm{km}$ from Walangama. Ambagahawewa adjoins a famous old pilgrimage centre. Over generations, these potters have developed a reputation for superior wheel-thrown pottery, which they sell to pilgrims and to wholesalers who come from throughout the island. They do not eschew change: the community shares clay mills, some younger potters have adopted electric wheels, and new pottery styles are added when there is demand. But given the reliable market for their traditional pottery, they have stayed with wheelthrowing. Walangama, Kelinawala, and Ambagahawewa are not culturally distinct and all have benefitted from government programs. But locational subtleties have encouraged different trajectories.

Walangama's history also encourages us to think beyond the region. After Independence, Sri Lanka continued the social liberalism that had guided British colonial policy in the early $20^{\text {th }}$ century (Jayasuriya, 2001, p.3). This commitment brought Walangama, Kelinawala, and Ambagahawewa their coöperatives, improved potter's wheels, expansion land, and clay fields. In 1949, the government even banned the import of pottery from India to support the domestic industry (Samarasinghe, 1956, p.J83). That same approach to protecting the local economy also raised the cost of vehicles with high import dues, which is probably why the
Walangama coöp was not allowed to buy its own lorry. But for Walangama, this later turned out to be advantageous. Village men rented vehicles, developed experience with contracts, and built contact networks. They were thus well positioned to expand into curd pots when the opportunity arose after the economy was liberalised in 1977.

Thus, we can see that the Walangama potters and their wheels are embedded in a variety of systems that interact at multiple spatial and temporal scales. In this complex and dynamic world, we are led to focus on "emergence, rather than existence" (van der Leeuw, 2020, p.104). The technology we are trying to describe is always in the process of becoming.

\section{Conclusion}

"Any attempt to deal with the morphogenetic properties of dynamic systems must acknowledge the important role played by unforeseen events and the fact that actions often combine to produce phenomena we might define as the spontaneous structuring of order" (van der Leeuw, 2020, p.106).

There was a time when the potters of Walangama wanted only to be rice farmers. For generations, it was their most esteemed subsistence activity, promising both food security and social status. But by the mid-twentieth century, they did not have, and could not get, enough farm land to support their growing population. So, they accepted what was afforded them. As a result, new and unanticipated futures emerged, different ways of being and different sorts of security. Walangama's potter's wheel story illustrates how this technology, perhaps any technology, exists in a dynamic, historical, inter-scalar web of connections. Looking back, we can identify the reasons why these potters adopted the ball-bearing wheel when they had the opportunity. But it would have been hard to foresee the complex series of linked developments that emerged, leading eventually to that wheel's partial abandonment.

\section{Acknowledgements}

An earlier version of this paper was presented at the University of Amsterdam conference, Archaeological Approaches to the Study of the Potter's Wheel (24-27 November, 2020). The author thanks the conference organisers for including her in this stimulating event, and the conference participants as well as IANSA reviewers for their essential feedback. Research was supported by the National Science Foundation (NSF) Cultural Anthropology Program (1974-1976, 1992); the American Institute for Sri Lankan Studies (2003-2004); the University of New Hampshire (2004); the United States-Sri Lanka Fulbright Commission (2013); and a NSF Long Term Professional Development leave (2013). Writing was done as a Senior Scholar at the School for Advanced Research, Santa $\mathrm{Fe}$, New Mexico. Any opinions, findings, or conclusions 
expressed here are those of the author and do not necessarily reflect views of funders or other supporters whose generosity is gratefully acknowledged.

\section{References}

ALLEN, P.M., VARGA, L., and STRATHEM, M., 2010. The evolutionary complexity of social and economic systems: the inevitability of surprise Risk Management, 12(1), 9-30.

ARULPIRAGASAM, A., 1955. Administration report of the Government Agent for the Kurunegala District for 1954. Colombo: Government Press.

ATHUKORALA, P., and JAYASURIYA, S., 1994. Macroeconomic policies, crises, and growth in Sri Lanka, 1969-1990. Comparative Macroeconomic Studies. Washington, D.C.: The World Bank.

BERG, I., 2020. The potter's wheel. In: C. Smith, ed. Encyclopedia of global archaeology. $2^{\text {nd }}$ ed., Cham, Switzerland: Springer. DOI: 10.1007/978-3319-51726-1 3443-1.

COOMARASWAMY, A.K., 1956 (1908). Mediaeval Sinhalese art. $2^{\text {nd }}$ revised ed. New York: Pantheon Books.

CREWE, L., and KNAPPETT, C., 2012. Technological innovation and island societies: wheelmade pottery on Bronze Age and Iron Age Crete and Cyprus. In: G. Cadogan, M. Iacovou, K. Kopaka, and J. Whitley, eds. Parallel lives: Ancient Island Societies in Crete and Cyprus. British School at Athens Studies, 20. London: British School at Athens, pp. 175-185.

DENHAM, E.B., 1912. Ceylon at the census of 1911. Colombo: H.C. Cottle, Government Printer.

EVELY, D., 1988. The potters' wheel in Minoan Crete. The Annual of the British School at Athens, 83, 83-126.

FERNANDO, S.C., 1951. Administrative report on the working of the co-operative societies from May 1, 1950, to April 30, 1951. Colombo: Government Press.

GAVAN, J. D., and CHANDRASEKERA, I.S., 1979. The impact of public foodgrain distribution on food consumption and welfare in Sri Lanka Research Report, 13. Washington, D.C.: International Food Policy Research Institute.

JAYASURIYA, L., 2001. The evolution of social policy in Sri Lanka, 1833 1970: the British colonial legacy. Journal of the Royal Asiatic Society of Sri Lanka (N.S.), 46, 1-68.

KNAPPETT, C., and VAN DER LEEUW, S., 2014. A developmental approach to an ancient innovation: the potter's wheel in the Bronze Age East Mediterranean. Pragmatics \& Cognition, 22(1), 64-92.

MAGRILL, P. and MIDDLETON, A., 2001. Did the potter's wheel go out of use in Late Bronze Age Palestine? Antiquity, 75(287), 137-144.

PANABOKKE, C.R., 1996. Soils and agro-ecological environments of Sri Lanka. Colombo: Natural Resources, Energy, and Science Authority.
PERERA, M.S., 1960. Administration report of the Director of Rural Development and Cottage Industries for 1959. Colombo: Government Press.

RICE, P.M., 1987. Pottery analysis: a sourcebook. Chicago: University of Chicago Press.

ROUX, V., 2010. Technological innovations and developmental trajectories: social factors as evolutionary forces. In: M.J. O'Brien, and S.J. Shennan, eds. Innovations in cultural systems: contributions from evolutionary anthropology. Cambridge: MIT Press, pp. 217-233.

ROUX, V., 2003. A dynamic systems framework for studying technological change: application to the emergence of the potter's wheel in the southern Levant. Journal of Archaeological Method and Theory, 10(1), 1-30.

SAMARASINGHE, G.V.P., 1956. Administrative report of the Director of Rural Development and Cottage Industries for 1955. Colombo: Government Press.

SARASWATI, B., and BEHURA, N.K., 1966 (1964). Pottery techniques in peasant India. Anthropological Survey of India, Memoir No. 13. Calcutta: Government of India.

SCHENK, H., 2001. The development of pottery at Tissamaharama. In: H-J. Weisshaar, and W. Wijeyapola, eds. Ancient Ruhuna. Sri LankanGerman Archaeological Project in the Southern Province, Vol. 1. Materialien Allgemeine und Vergleichende Archäologies. Mainz am Rhein: Verlag Philipp von Zabern, pp. 59-195.

SOMADEVA, R., 2006. Urban origins in southern Sri Lanka. Studies in Global Archaeology, 5. Kelaniya: University of Kelaniya, Postgraduate Institute of Archaeology.

VAN DER LEEUW, S., 2020. Social sustainability, past and future: undoing unintended consequences for the earth's survival. Cambridge: Cambridge University Press.

VAN LANGENBERG, W.J.A., 1951. Administrative report of the Acting Director of Industries for the years, 1940 to 1947. Colombo: Government Press.

WEERAHEWA, J., 2004. Impacts of Trade Liberalization and Market Reforms on the Paddy/Rice Sector in Sri Lanka. Discussion paper no. 70. Washington, D. C.: International Food Policy Research Institute.

WINSLOW, D., 1994. Status and context: Sri Lankan potter women reconsidered after fieldwork in India. Comparative Studies in Society and History, 36(1), 3-35.

WINSLOW, D., 1996. Pottery, progress, and structural adjustments in a Sri Lankan village. Economic Development and Cultural Change, 44(4), 701-733.

WINSLOW, D., 2003. Potters' progress: hybridity and accumulative change in rural Sri Lanka. The Journal of Asian Studies, 62(1), 43-70.

WINSLOW, D., 2009. The village clay: innovation, recursion, and community in a Sri Lankan village. JRAI: Journal of the Royal Anthropological Institute NS, 15, 254-275.

WINSLOW, D., 2016. Living life forward: technology, time, and society in a Sri Lankan potter community. Economic Anthropology, 3, 216-227. 
